\title{
Selective Glucocorticoid Receptor Antagonist CORT125281
}

National Cancer Institute

\section{Source}

National Cancer Institute. Selective Glucocorticoid Receptor Antagonist CORT 125281.

NCI Thesaurus. Code C153309.

An orally available, selective glucocorticoid receptor (GR) antagonist, with potential antineoplastic activity. Upon oral administration, CORT 125281 competitively and selectively binds to GRs, inhibiting the activation of GR-mediated proliferative and antiapoptotic gene expression pathways. The GR, a member of the nuclear receptor superfamily of lig and-dependent transcription factors, is overexpressed in certain tumor types and may be associated with tumor cell proliferation and treatment resistance. Inhibition of GR activity may potentially slow tumor cell growth and disease progression in certain cancers. 